\title{
MODERN CONCEPT OF CHILDREN'S PRESCHOOL EDUCATION: CHANGES AND CHALLENGES
}

\author{
Daiva Malinauskienė \\ Šiauliai University, Lithuania
}

\begin{abstract}
The article deals with a modern concept of children's preschool education and scientific research meant to substantiate a positive impact of high-quality preschool education on a child's life and his/her academic achievements in future. The analysis of foreign and national sources, research and strategic documents on education focusing on the evaluation of essential changes in the sector of preschool education and the discussion of the prospects of institutional preschool education has been conducted. The issues that must inevitably become a part of the work schedule of the Lithuanian education policy have been distinguished: accessibility of educational institutions, high quality (self-)education, the necessity of help for a child belonging to a risk group, ensuring education and social services for families and children in poverty, education of talented and gifted children, the situation of (self-)education of children in rural areas and other issues that are important for the practice of children's (self-)education of today.
\end{abstract}

Keywords: changes and challenges of preschool education, high-quality education, preschool education.

\section{Introduction}

In the recent decade in the education system of Lithuania quite many important strategic decisions that influenced the essential changes in the sector of preschool education have been taken. The changes have taken place in many fields of the system of preschool education - methodological field, the fields of the contents, process and methods of education, types and structure of institutions, teacher training and in-service training, the management and development of facilities (Monkevičienè et al., 2009). One of possible impulses of the occurrence of these changes was the project "Development of Preschool and Pre-primary Education" started to be implemented in Lithuania in 2009 and financed by the structural funds of the European Union (hereinafter EU). The aim of the project is "to enhance the availability and variety of preschool/preprimary education, especially in rural areas, decreasing social exclusion and differences between municipalities; to ensure flexible and high-quality services, necessary educational support taking children's individual educational needs into account" (About the Project, 2012). The project is the component of the Programme of the Development of Preschool and Pre-primary Education for 
Daiva Malinauskiene. Modern Concept of Children's Preschool Education: Changes and Challenges

2011-2013 of the Ministry of Education and Science of the Republic of Lithuania.

Ambitious aims of the reconstruction of the preschool sector initiated by the Ministry of Education and Science of the Republic of Lithuania and the project obliged the educational community to achieve measurable results in quite a short time.

To ensure the development of preschool and pre-primary education Methodical Recommendations on the Variety of Forms of the Organization of Preschool Education (2013), Methodical Recommendations for Nongovernmental Providers of Preschool and Pre-primary Education (2013) have been prepared. In order to help preschool education teachers to get to know a modern child better and to more purposefully adjust educational aids to the needs and abilities of a particular child Description of Achievements of Preschool-age Children (2014) and Methodical Recommendations for Preschool Education (2015) have been prepared. General Curriculum of Pre-primary Education (2014) and other documents that help teachers to forecast successful directions of activity for child's high-quality (self-)education and (self-) assessment of achievements, etc. have been updated.

Obvious changes are being observed in other fields of preschool education as well: preschool institutions are being modernized, innovative models of the organization of preschool education, because of which the quality of education becomes higher, are being implemented, private preschool institutions and multifunctional centres are being more and more actively established (until 2015 it was forecast that in municipalities 78 centres would have been opened), new preschool education groups in general education schools are being created, new workplaces for pedagogical and other employees and coordinators of interinstitutional collaboration who would render support for children from their birth to 7 years of age are being established (The Implementation of the UNESCO Initiative Education for All in Lithuania, 2014). One more important change that took place in the system of education and came in force from 1 September, 2016 is compulsory pre-primary education in Lithuania that that will help children to appropriately get ready for school.

Changes in the sector of preschool education are characteristic not only to Lithuania. In Europe early childhood education, especially of children from families of social risk and exclusion, is considered a priority field of education, which is reflected in the main EU strategic document "Europe 2020", the strategy of smart, sustainable and inclusive growth. This document according to the exemplary initiative "Mobile Youth" obliges the partner states to uphold all the fields of the system of education and training including preschool and general education: allocate necessary funds, improve educational outcomes, coordinate the curriculum with the demands of future education and labour 
market. "Implementing the programme "Education 2020" the European countries strive that at least 95 per cent of children from 4 years of age to the age when education is compulsory participate in early childhood education. Most of the European countries committed to ensure places for education for all children or legally establish that education is compulsory at least in the last year of preschool education" (Pre-primary education - from Comprehensive to Compulsory, 2014, p. 1). The actions of the accessibility and improving quality of preschool education are set in another Communication from the European Commission "Early Childhood Education and Care: Providing all our children with the best start for the world of tomorrow" (2011).

Strategic documents of Lithuania that set the priorities of education are congruent with the EU strategy "Europe 2020". In the National Strategy for Education for 2013-2022 (2013) much attention is paid to preschool education speaking about the aspects of its accessibility and quality. In Lithuania's Progress Strategy "Lithuania 2030" it is also emphasized that it is important "to ensure the accessibility of preschool childcare institutions. This aspiration is a component of the initiative of strengthening the institution of family establishing favourable conditions to balance the commitments of family and work" (Lithuania's Progress Strategy "Lithuania 2030", p. 12).

Contemporary policy of preschool education of Lithuania demands to give an opportunity to children and their families to use other services provided by the state as well: provide bigger support for working families, create more diverse forms of educational and social services corresponding to parents' and children's needs, look for various models of financial support to families with low income as well, etc. (Monkevičienè et al., 2008). However, there still remain problems to be solved that should become a part of the work schedule of the education policy: accessibility of education and ensuring its quality, support for children at risk, necessity for educational and social services for a family and its children in poverty, education of talented and gifted children, the situation of the education of rural children and other issues that are important for children's further high-quality (self-)education, their academic achievements, social adaptation skills necessary in the competitive and knowledge-based society of today.

The object - modern concept of children's preschool education.

The aim of the research - to analyse the modern concept of children's preschool education, the research conducted in Lithuania and abroad in the field of high-quality preschool education revealing the changes of this education and the challenges it faces.

Methods: analysis of scientific literature and strategic documents of education, meta-analysis. 


\section{Substantiation of the importance of preschool education in a child's life}

In Lithuania preschool education is a primary element of the system of education that is developed with regard to general ideas of the education of the society and an individual (a child). This primary element is given quite much attention in the education system of Lithuania. Lithuania, focusing on the EU education policy directed towards the integration of educational and social services providing support for a child and family, turns from a narrow specialization of an institutional direction (nursery school, kindergarten, care home) to comprehensive education (Development of Preschool Education: Will We Change the Model of Financing? 2006, p. 2).

In Lithuania preschool education is started to be provided from the child's birth until he/she is provided with pre-primary education (Law on Education of the Republic of Lithuania, 2011). In scientific literature and strategic documents of education it is emphasized that preschool education is a primary and basic element of (self-)education of an individual, on the basis of which education in other elements can be realized. Today pedagogues, researchers, strategists of the education policy and all who care for the welfare and education of a young child do not doubt that it is in childhood when the basement of child's successful future is laid. It is stated that:

- $\quad$ early childhood is a special period important for child's purposeful and high-quality (self-)education and life in present and future.

- High-quality education positively influences children, however, it becomes especially important for children growing under the conditions of social risk and social exclusion, their further social and emotional development, helps to reduce poverty.

Analogous conclusions have been presented by the group of researchers (Taggart et al., 2015), who have generalized the results of the biggest (from the aspect of sample) and the longest in Europe (from the aspect of time: 19972014) scientific research "Effective pre-school, primary and secondary education project (EPPSE 3-16+)". The researchers in 141 preschool education institution of the United Kingdom monitored 2800 children (from 3 years of age until the end of their compulsory education at school), who were growing in poor families and were not attending preschool education institutions and those who were growing in well-off families and were attending preschool education institutions. The results of the research have revealed enormous differences in children's achievements (over 38 per cent) in future and big added value of high-quality early education. It was identified that there was a big probability that children who had been growing in poorer families and not attending preschool education institutions later were worse at learning and when grown up 
they live on the dole or even tend to delinquency. The researchers' insights were confirmed after more than ten years when the children under monitoring were already 16 years old and were taking graduation examination that is compulsory in the country. The results of the test confirmed that the influence of highquality preschool education remains for a very long time; child's early experience that he/she gains while attending a preschool education institution determines how good he/she will be at learning in future, what his/her achievements in the fields of reading, mathematics, nature sciences and other fields will be. It is also illustrated by the results of international (TIMSS, PIRLS, PISA) research.

The Lithuanian scientists O. Monkevičienè, V.S. Glebuvienè, K. Stankevičienè, M. Jonilienė, S. Montvilaitè, A. Mazolevskienė (2009) have analysed and generalized many researches conducted by foreign scientists where the advantages of high-quality preschool education were revealed and the achievements of children attending and not attending kindergarten were compared. The researchers have presented the conclusions of the analysis stating that "children's achievements in the stage of high-quality preschool education have direct influence on the development of a child's communication in the native language; high-quality education enables immigrants' children to learn a state language; those who received high-quality educational services in their early childhood learn more diligently, more persistently seek higher education; high-quality education has influence on the development of children's interpersonal, intercultural, social relations; the participants of the research who attended preschool educational institutions tend to act responsibly to a greater extent, take care of their health; high-quality preschool education ensures a financial return in future" (Monkevičienè et al., 2009, p. 31).

Consequently, the results of the research on the impact of high-quality preschool education oblige to strive for making education accessible and giving every child an opportunity to receive high-quality educational services as early as possible. It should be one of the main educational priorities of every country. Regarding this issue the situation of Lithuania of today is not good enough. In the Education and Training Monitor 2015 of the European Commission (2015, p. 6-7) it is stated that the "participation of four year olds in ECEC was $86.5 \%$ in 2013, noticeably below the EU average of $93.1 \%$ ". The situation is even more worsened by the data of the Department of Statistics of Lithuania of the year of 2014 that illustrate that the level of the participation in these programmes in rural and urban areas differs almost by 50 percentage points (92,2 \% in urban and $42,8 \%$ in rural areas). Partially it is because of insufficient accessibility of schools in rural areas. The national aim of Lithuania set in the National Strategy for Education for 2013-2022 (2013) is to ensure that in 2017 the institutions of early education and care would be attended by 90 per cent of 
four year olds, meanwhile in 2022 - by 95 per cent of four year olds (Education and Training Monitor 2015, 2015, p. 6). Due to the fact that so far in Lithuania preschool education is not compulsory, it is rather an ambitious aim, to fulfil which it is possible only by revising the priorities of the education policy of the state and municipalities and joining up the efforts of all the participants of the process of education.

\section{Challenges that preschool education faces}

While reviewing the essential changes of the recent years that took place in the sector of preschool education in Lithuania we notice that indeed much work has been done implementing the aims and objectives set for the development of preschool education in strategic documents of education. However, the retrospective analysis of the change allows stating that the aim set more than two decades ago - "to guarantee happy childhood to a child, to ensure child's physical, psychical and social welfare not violating his/her rights" - is still relevant today as well" (Concept of Preschool Education of the Republic of Lithuania, 1989, p. 59).

The preschool education policy of today in Lithuania is inseparable from the main landmarks and values of the development of education of the European Union. Although in Lithuania the scope of preschool education is increasing, however, it is still not sufficient. Striving for higher quality of children's education, the welfare and security of families, the promotion of national identity in many strategic educational documents of Lithuania and Europe the most important challenges that preschool education faces have been highlighted. Some of the challenges are especially relevant to Lithuania (The Presentation of the Description of Achievements of Preschool-age Children and Methodical Recommendations for the Preparation of Curriculum Programmes of Preschool Education at Municipalities, 2013):

- Accessibility of education. The issue of accessibility is especially relevant to children living in bigger cities and rural areas.

- Early childhood education. In many countries of Europe including Lithuania education starts from the birth. There is a tendency to make the beginning of compulsory education earlier.

- Aims of child's education and their implementation. The countries of Europe including Lithuania intensively and purposefully strive for higher quality of preschool education. The set aims and the ways of their implementation in different countries can be different, however, referring to the attitude accepted in many countries that a child is in the centre of preschool education, education should be based on the child-focused paradigm that requires a holistic approach towards 
child's personality, the skills he/she possesses and the desires to act freely and not being restricted by anyone.

- Child's achievements and their evaluation. It is an important factor to know children and their development better and improve the quality of education. The evaluation of child's achievements allows observing the progress the children make and forecast the guidelines of further (self-) education. In many countries much attention is paid to early monitoring of child's progress.

- Child's knowing how to learn. It is one of the main competences that become especially important at preschool age. Other not less important competences - social, health protection and strengthening, cognition, communication, artistic.

- Early teaching of foreign language(s). When Lithuania became the member state of the EU early teaching of foreign languages is becoming an important challenge not only in primary classes but also at preschool age.

- Education of bilingual, multilingual children and children speaking other languages. To make the education of such children successful the partnership of the educators (parents, pedagogues, children, other specialists) is necessary tolerantly accepting cultural and social differences of families, respecting their native language, religion, traditions and customs.

- Education of children with special educational needs. The success of education will depend on the friendly attitude of the community of the institution (and the society) and collaboration, suitably chosen methods of (self-)education, adjustment of educational environment, etc.

The challenges that are raised clearly define particular aims and directions of further activity that should be a priority in the education of today and for which we should strive responsibly, initiatively and consistently for the sake of high-quality (self-)education of our children.

\section{Conclusions}

- In scientific literature and many strategic documents of education it is emphasized that preschool education is a primary and basic element of individual's (self-)education, on the basis of which education in other elements can be successfully realized.

- Scientists discussing the importance of high-quality education to a child state that early childhood is a special period important for child's 
purposeful and high-quality (self-)education and life in present and future. The research has proven that high-quality early education positively influences all children. However, it becomes especially important for children growing under the conditions of social risk and social exclusion, their further social and emotional development, helps to reduce poverty and gives more opportunities to have higher academic achievements in future.

- In many strategic educational documents of Lithuania and Europe the challenges that preschool (self-)education faces have been highlighted: accessibility of education; early childhood education; aims of child's education and their implementation; child's achievements and their evaluation; child's competences; child's knowing how to learn; early teaching of foreign language(s); bilingual education; education of children with special educational needs.

\section{References}

Apie projekta. (2012). Downloaded from http://www.ikimokyklinis.lt/index.php/ipupprojektas/apie-projekta/11671

Europa (2020). Downloaded from http://ec.europa.eu/europe2020/index_en.ht.

Europos Komisijos komunikatas. Ankstyvasis ugdymas ir priežiüra. Kaip padèti mūsu vaikams kuo geriau pasirengti ateičiai. Briuselis, 2011.2.17 COM (2011). 66).

Europos Komisijos 2015 metu švietimo ir mokymo stebèsenos biuletenis. (2015). Lietuva. Liuksemburgas: Europos Sajungos leidinių biuras.

Ikimokyklinio amžiaus vaiku pasiekimu aprašas. (2014). Downloaded from http://www.smm.lt/uploads/documents/Pedagogams/ikimok_pasiekimu_aprasas.pdf

Ikimokyklinio amžiaus vaiku pasiekimu aprašo ir ikimokyklinio ugdymo turinio programu rengimo metodiniu rekomendaciju projektu pristatymas savivaldybèse (2013). [PowerPoint slides]. Downloaded from http://www.ikimokyklinis.lt/uploads/ files/dir650/dir32/dir1/9_0.php

Ikimokyklinio ir priešmokyklinio ugdymo pletros 2011-2013 metu programa. (2011). Patvirtinta Lietuvos Respublikos švietimo ir mokslo ministro $2011 \mathrm{~m}$. kovo $1 \mathrm{~d}$. isakymu Nr. V-350. (Žin., 2011.03.10, Nr.: 30 - 1421).

Ikimokyklinio ugdymo kokybè. (2012). Švietimo problemos analizė, 13 (77). Downloaded from http://www.nmva.smm.lt/wp-content/uploads/2012/12/Ikimokyklinio-ugdymokokybe-2012-rugs\%C4\%97jis.pdf

Ikimokyklinio ugdymo pletra: ar keisime finansavimo modelį? (2006). Švietimo problemos analize, 8 (11). Downloaded from https://www.smm.lt/uploads/documents/ kiti/Finansavimo_modelis.pdf

Lietuvos pažangos strategija „Lietuva 2030”. Downloaded from file://C:/Users/ASUS/ Downloads/Lietuva2030\%20(5).pdf

Lietuvos Respublikos švietimo ir mokslo ministerija. (2014). Priešmokyklinio ugdymo bendroji programa. Kaunas: Šviesa.

Priešmokyklinis ugdymas - nuo visuotinio prie privalomojo. (2014). Švietimo problemos analize, 11 (116). Downloaded from file:///C:/Users/ASUS/Downloads/\%C5\%A0 
vietimo\%20problemos\%20analiz\%C4\%97.\%20Prie\%C5\%A1mokyklinis\%20ugdymas \%20\%E2\%80\%93\%20nuo\%20visuotinio\%20prie\%20privalomojo\%20(2).pdf

Lietuvos Respublikos švietimo ir mokslo ministerija. (2015). Ikimokyklinio ugdymo metodinès rekomendacijos. Klaipėda: UAB „Baltic Printing House“.

Lietuvos Respublikos švietimo ir mokslo ministerija. (2006). Metodinès rekomendacijos ikimokyklinio ugdymo programai rengti. Vilnius: Švietimo aprūpinimo centras.

Lietuvos Respublikos švietimo įstatymas. (2011). Valstybès žinios, 2011-03-31, Nr. 38-1804.

Lietuvos statistikos departamento leidinys „Švietimas $2013 \mathrm{~m} . “$ (2014). Prieiga internetu: https://www.google.lt/webhp?sourceid=chrome-instant\&ion=1\&espv=2\&ie=UTF-

$8 \# q=$ Lietuvos+statistikos+departamento+leidinys+\%C5\%A0vietimas+2013+m.+(2014)

.+Prieiga+internetu:+http://osp.stat.gov.lt/services-portlet/pub-edition-

file\%3Fid\%3D3070

Lietuvos vaikų ikimokyklinio ugdymo koncepcija. (1989). Tautiné mokykla I. Mokyklu tipu koncepciju projektai. Kaunas: Šviesa. 57-80.

Metodines rekomendacijos dèl ikimokyklinio ugdymo organizavimo formu ìvairovès. (2013). Downloaded from: http://www.kaunas.lt/wp-content/uploads/sites/8/2015/07/ rekomendacijosd\%C4\%971IUmodeli\%C5\%B3.pdf

Metodinès rekomendacijos nevalstybiniams ikimokyklinio ir priešmokyklinio ugdymo teikejjams. (2013). Downloaded from: http://www.kaunas.lt/wp-content/uploads/ sites/13/2015/04/rekomendacijosnevalstybiniusteigejams2013061.pdf

Monkevičienė, O., Glebuvienė, V. S., Jonilienè, M., Montvilaitė, S., Stankevičienė, K., Mauragienè, V., \& Tarasonienė, A. L. (2008). Ikimokyklinio ugdymo ịvairové: esama situacija ir visuomenès lūkesčiai (mokslinis tyrimas). Downloaded from: http://www.smm.lt/svietimo_bukle/docs/tyrimai/sb/VPUataskaita-paslaugivairove.pdf>.

Monkevičienė, O., Glebuvienė, V. S., Stankevičienè, K. Jonilienè, M., Montvilaitè, S., \& Mazolevskienė, A. (2009). Ikimokyklinio, priešmokyklinio ugdymo ir jo igyvendinimo kokybés analizé. Ataskaita. Downloaded from: http://www.upc.smm.lt/projektai/pletra/ Tyrimai/VPU\%20tyrimo\%20ataskaita/Ikimokyklinio,\%20priesmokyklinio\%20ugdymo $\% 20$ turinio\%20ir\%20jo\%20\%20igyvendinimo\%20kokybes\%20analize\%20Tyrimo\%20 ataskaita\%202009\%2011\%2005.pdf

Taggart, B., Sylva, K., Melhuish, E., Sammons, P., \& Siraj, I. (2015). Effective pre-school, primary and secondary education project (EPPSE 3-16+). Downloaded from: https://www.gov.uk/government/uploads/system/uploads/attachment_data/file/455670/ RB455_Effective_pre-school_primary_and_secondary_education_project.pdf.pdf

Švietimas visiems UNESCO iniciatyvos igyvendinimas Lietuvoje. (2014). Downloaded from https://www.smm.lt/uploads/lawacts/docs/764_107f2f0d6f59f3b3e36f6c5541569414.pd $\mathrm{f}$

Valstybine švietimo 2013-2022 metu strategija. (2013). Downloaded from https://www.smm.lt/uploads/lawacts/docs/451_f91e8f0a036e87d0634760f97ba07225.p df 